\title{
FUNCTIONAL DIVERSIFICATION OF POST-WAR NEIGHBOURHOODS - NOVI SAD CASE STUDY
}

\begin{abstract}
This paper discuss the mass housing neighborhoods named Limans in Novi Sad, Serbia, with the specific case study of urban quarter named Liman 3, showing a good example of gradual functional diversification of neighborhood since post-war period up to present days. The research approach of the paper is based on combination of Space Syntax, Spacematrix and Mixed-use index tool, as well as on contextual analysis with the specific interest on societal and economical issues. Aim of the paper is to show how local circumstances joint with global influences, evident in the example of Liman 3 urban area, have induced transition from completely residential to moderately mixed-use neighborhood during more than 40 years development period.
\end{abstract}

Keywords: Novi Sad, residential neighborhoods, land-use patterns, mixed uses, Mixed-use index.

\section{Introduction}

Political priorities in post-war Yugoslavia, common to Central and Eastern Europe countries at that time, have led to the massive construction of residential areas in the cities. As the overall progress in former Yugoslavia has been delivered with delayed effects and consequences, urban development in the city of Novi Sad, Serbia, was no exception. Conditions for intense expansion of Novi Sad were achieved only in the sixties - almost twenty years after the end of the World War II. This paper discusses the mass housing neighborhoods named Limans in Novi Sad with the specific case study of urban quarter named Liman 3, showing a good example of gradual functional diversification of neighborhood.

Limans are urban quarters situated on the left bank of the Danube river, in close proximity to the city centre. Typical morphology of these quarters was completely in accordance with the urban doctrine at the time. Residents were provided with enough sun, space and greenery, but the quality of life was not fully accomplished. The older parts of Liman 3 were designed as so-called dormitory neighborhoods, 
common for the period of mass housing production and characterized by a negligible number of non-residential facilities. Only in the late $20^{\text {th }}$ and early $21^{\text {st }}$ century, favorable conditions for the construction of a significant number of non-residential facilities were created, which has changed the ratio between the uses and functional balance. The aim of the paper is to show how local circumstances joint with global influences, as shown in the example of Liman 3 urban area, have induced the transition from completely residential to the moderately mixed-use neighborhood during more than 40 years of development period.

\section{Methodology}

Previous research of the land-use patterns showed the diversity of issues and complexity of relations among land-use patterns and other urban phenomena in the contemporary city. The research approach of the paper is based on the combination of Space Syntax ${ }^{1}$ (for movement network analyses), Spacematrix ${ }^{2}$ (for densities analyses) and Mixed-use index tool ${ }^{3}$ (for land-use analyses), as well as on contextual analysis with the specific interest on societal and economic issues. Urban indexes are calculated for block segments (shown in Graph 1 and Graph 3) and for the whole sample of Liman 3 (shown in Table 1).

\section{Broader context}

Accelerated industrialization and urbanization after World War II has initiated mass construction of modern residential neighborhoods as one of the political priorities in Yugoslav cities. Newly born state of Yugoslavia gradually established specific form of government, the liberal socialism, which resulted in strong economic development of the country, especially in the 1960s and $1970 \mathrm{~s}^{4}$. New socio-economic circumstances boosted the need for new society to be marked in space or through space (Pušić 2009). That is the reason why residential neighborhoods

\footnotetext{
${ }^{1}$ A formal way of looking at cities that sets out from the study of the network of space - streets and roads - that holds the system together (Hillier 2009).

${ }^{2}$ In Spacematrix, density is defined as a multi-variable phenomenon to be able to relate density and urban form (Berghauser Pont, Haupt 2009).

${ }^{3}$ Defined by J. van den Hoek (2009) and here used redefined version where uses are classified on residential, primary non-residential and secondary (non-residential) uses (Carević 2017), based upon Jane Jacobs's theory (Džejkobs 1961/2011).

${ }^{4}$ Such a powerful economic development has led to the fact that most of the population had a living standard never witnessed before: free education at all levels, free health services, apartment, car, cottage, summer and winter holidays, travelling around the world, training and education. Wages and personal standards of a great share of the population at that time have been even higher than in some Western countries (Srbulović 2000).
} 
have been built according to the modernistic urban ideas which mostly resulted in monofunctional residential zones. Conditions for intensified expansion of Novi Sad towards the South to the Danube were created by the relocation of the railroad in the 1960s when the construction of multifamily housing on the Limans begins. The construction has been done in several phases while some parts of the area are still waiting for the completion.

In the modern de-industrialized city the conditions for the mixed-use construction are more favorable than ever before, due to the predominance of the knowledge economy and the service sector. The overall modern lifestyle in the city, along with transformed business operation modes, dependence on global socio-economic flows, and heterogeneity of lifestyles had formed the framework for transition from monofunctional to polyfunctional spatial planning. Similarly, in recent years Novi Sad has witnessed the expansion of IT sector which nowadays represents one of the main potentials for economic development, positioning the city as "the capital of IT sector in Serbia" and even "the European IT Center" (KLER 2011). Increased entrepreneurship initiatives in the tertiary sector and the entry of foreign companies into the local market generated an increased demand for space that would qualitatively and quantitatively meet the standards and requirements of modern business operation (Nedučin 2014).

Restructured economy has also influenced changes in spatial distribution of work activities in the city. Recent decades have witnessed a gradual mixing of residential and business programs, and increasing share of businesses in traditionally residential areas, as a result of both the planning measures, as well as the citizen initiatives.

\section{Case study - Liman 3}

The selected fragment is located between Bulevar cara Lazara street, Bulevar oslobodjenja, Bulevar Despota Stefana and Balzakova street (Fig. 1), about $2 \mathrm{~km}$ from the city center. Due to the Modernistic construction style, there are only 5 superblocks on the area of 57 ha. For the purpose of more precise research results, these blocks were divided during the calculation so they form the fragments defined by the local street network. The basic character of Liman 3 is reflected in multifamily housing, although main streets contain non-residential facilities comprising local linear centers and connecting the area with other parts of the city. The near surrounding of the fragment consists of residential areas, the marketplace, the post office and the headquarters of the company for electricity distribution, as well as the student dormitories and partly revitalized former industrial zone. 


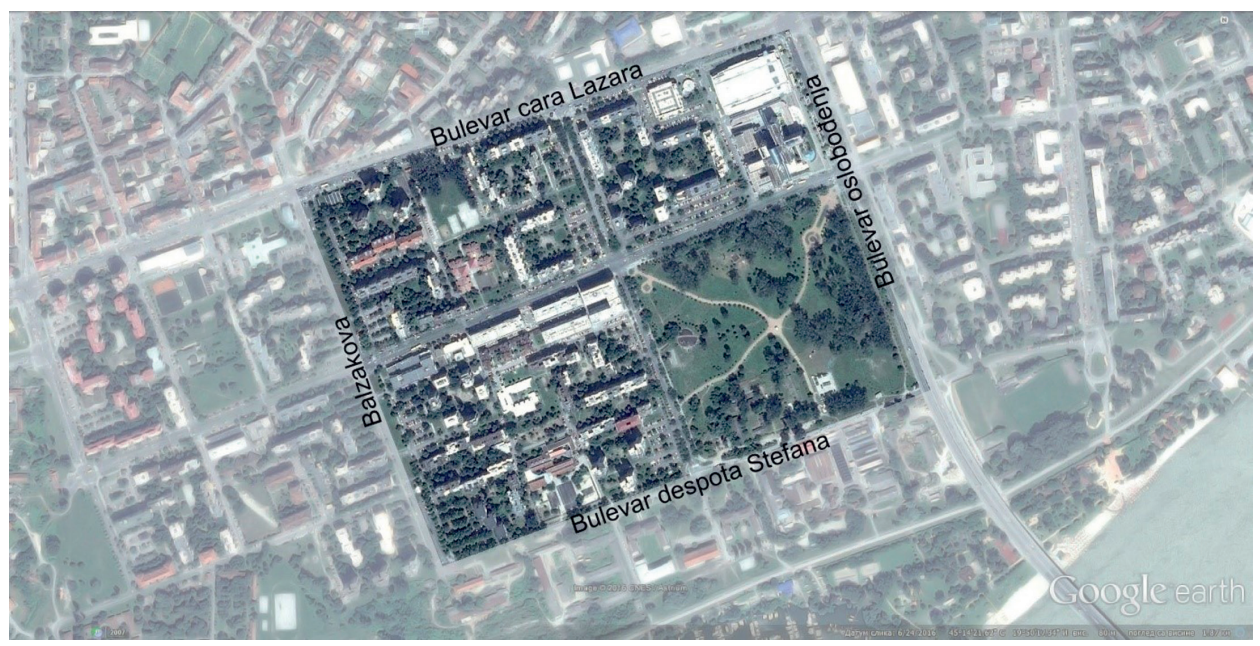

Figure 1. Case study area - Liman 3

Source: Google Earth, adapted by D. Tomić

\subsection{Development of Liman 3}

The construction of multifamily housing on Liman 3 started in 1970, on the formerly unregulated territory of Veliki Liman (Large Liman), located between the old railway station and the industrial zone. Overcoming the concept of dormitory neighborhood (Jovanović 2011), parallel to the construction of residential buildings, the inner spaces with greenery, the park, playgrounds, sports field, and parking places were also created, along with the preschool and the elementary school - altogether indicating the attention dedicated to the quality of life of future residents.

Following decades has brought new programs and large-scale developments on Liman 3, accompanied with just a few new multifamily residential buildings. Considering future perspectives, construction of the new music and ballet school on one of the undeveloped plots should contribute to the functional diversity of the area. The intensive construction of housing estate in Novi Sad, which started at the end of the $20^{\text {th }}$ and the beginning of the $21^{\text {st }}$ century, has left no evidence on Liman 3 neighborhood - even though the building roofs are flat, there is still a small number of upward building extensions, contrary to some other parts of the city. On the other hand, recent unsystematic individual adaptations aimed at improving the thermal comfort in flats threaten to undermine the character of the architecture of this part of the city. 


\subsection{Morphology and open spaces}

The typical morphology of Liman 3 is in accordance with urban practice of that time. Since the blocks are very large, the buildings were arranged on the whole area but forming human scale entities. These open or semi-open „subblocks" are also used in numerical calculations done for the purpose of the research presented in this paper. The Ground space index (GSI) in these sub-blocks range from $9 \%$ to $24 \%$, and they are clearly grouped in the diagram (Graph 1 ). The massive volumes of residential buildings have 8 floors on average, resulting in significant Floor Area Ratio (FAR) - generally between 1.0 and 2.0. Therefore, the open space ratio (OSR) is usually between 0.5 and 1.0, regardless of the large of undeveloped area.

Over time, new urban ideas and plans resulted in the changed typology of the later built structures - primarily in terms of programs, but also considering other characteristics. Newly built segments are characterized by similar FAR, but greater coverage (GSI) (Graph 1). More recent construction was intended to improve the treatment of public spaces. These now free-standing buildings are positioned on the very regulation line of the blocks, resulting mainly in very narrow sidewalks, which, however, are inadequate to the current pedestrian flow.

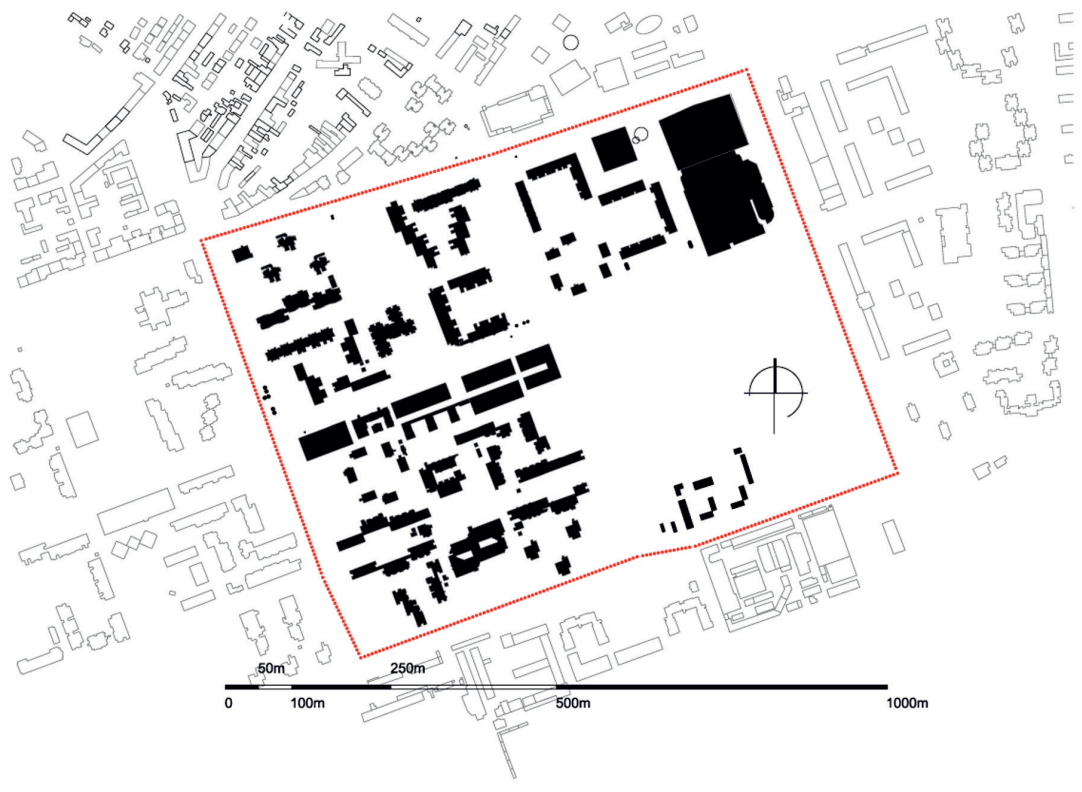

Figure 2. Black plan of Liman 3

Source: D. Tomić and S. Tomić 
Table 1. Numerical data for Liman 3 fragment

\begin{tabular}{|c|c|c|c|c|c|c|c|c|c|}
\hline 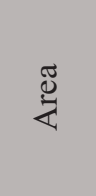 & 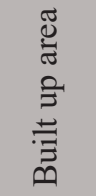 & 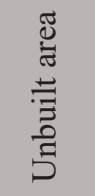 & 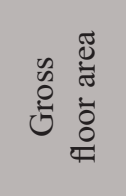 & $\vec{心}$ & $\underset{\mathbb{2}}{\stackrel{2}{x}}$ & 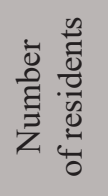 & 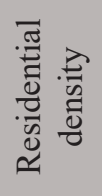 & 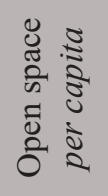 & $\frac{\mathscr{r}}{\mathscr{D}}$ \\
\hline ha & ha & ha & $\mathrm{m}^{2}$ & $\%$ & - & res & res/ha & $\mathrm{m}^{2} /$ res & - \\
\hline 56,98 & 10,13 & 46,85 & 561014 & 18 & 0,98 & 11476 & 254 & 40 & 0,84 \\
\hline
\end{tabular}

Network length: $6384^{*} 4808^{* *} \mathrm{~m}$

Network density: $112 \quad 84 \mathrm{~m} / \mathrm{ha}$

* Main roads and main inner-block paths are entered in calculations

** Only with main roads entered in calculations

Source: own elaboration

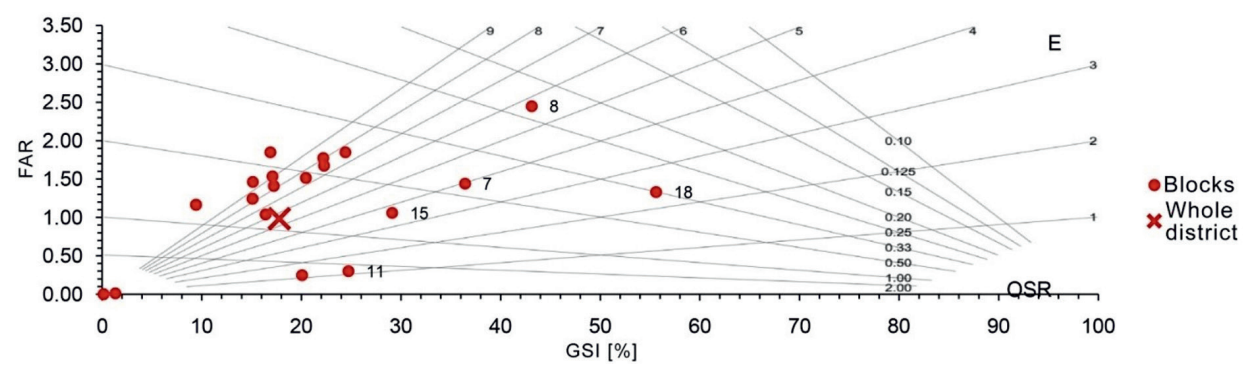

Graph 1. Spacemate diagram for Liman 3

Source: M. Carević Tomić

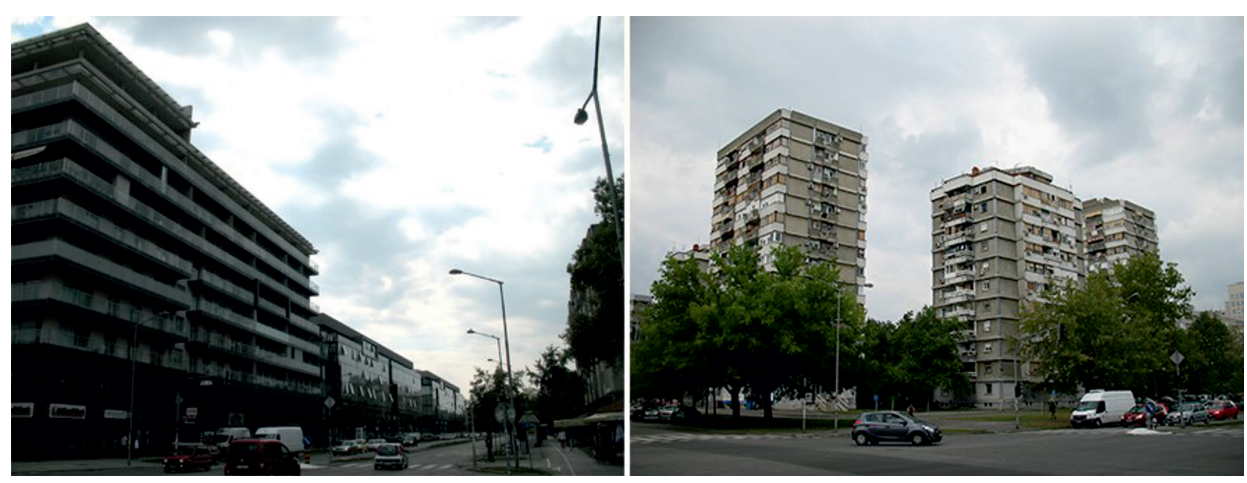

Figure 3. Typical Liman 3 environment

photo: M. Carević Tomić 


\subsection{Traffic analysis}

Liman 3 movement system consists of the primary network made of the main streets with wide cross-sectional profiles, and the secondary network, referring to inner-block roads. The spacious blocks result in small network density (Table 1), which has led to increased intensity of both vehicular and pedestrian movements along the main streets. Due to this fact and according to the Space Syntax calculations (Graph 2), routs with the greatest potential at the same time are parts with the greatest share of non-residential programs. Narodnog fronta Street is especially significant because it represents the axle that connects Limans and also functions as linear local center. It is interesting to note that, although planned as temporary structures, many kiosks and small shops set and built along this rout, have stayed for decades and are still functional. This is also the area where informal street vendors mostly gather, indicating together with previous observation that the intensity of pedestrian movements is of the great importance for the development of both the outdoor and indoor activities.

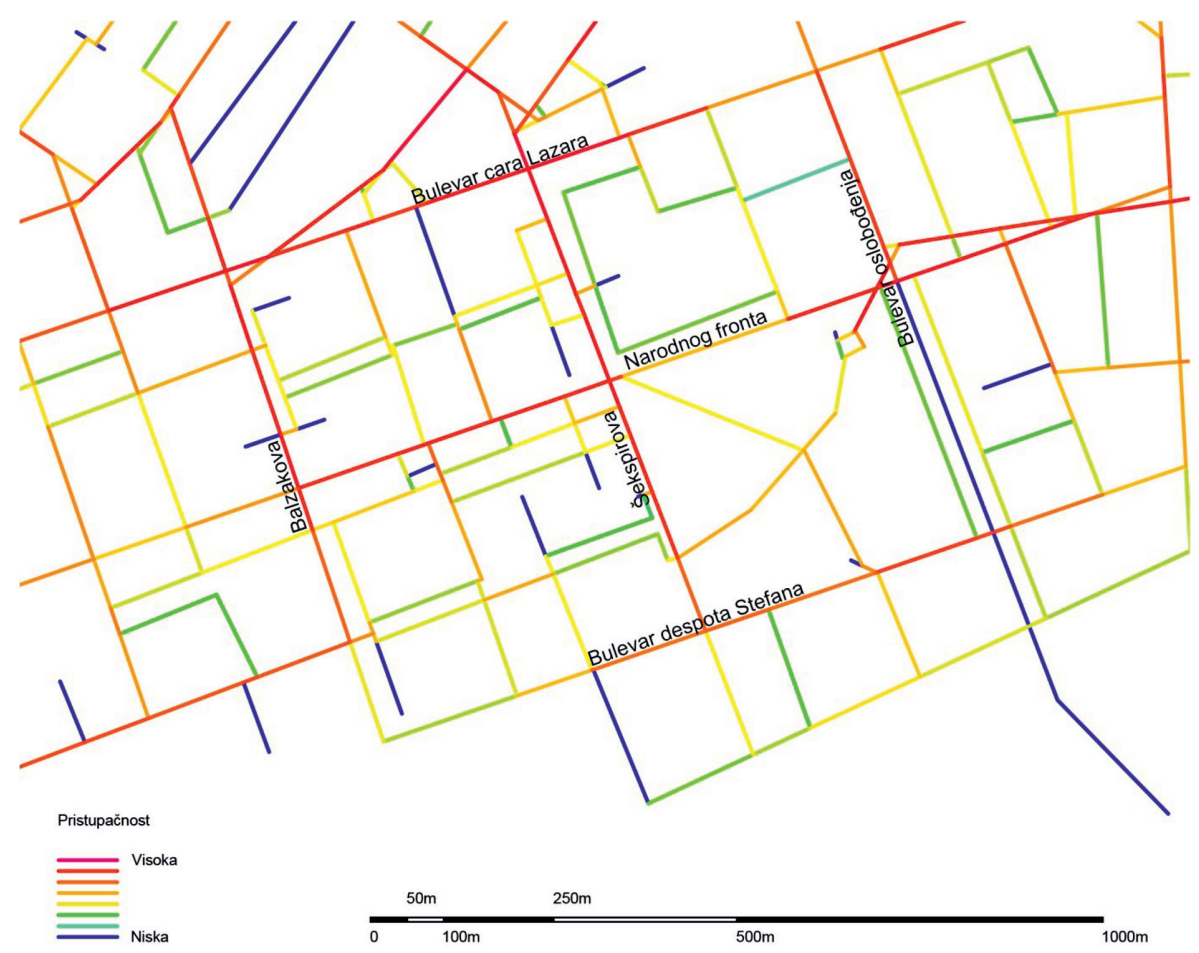

Graph 2. Spatial accessibility for Liman 3 - through-movement potential for combination of local $(400 \mathrm{~m})$ and global radius

Source: M. Carević Tomić 


\subsection{Land use patterns}

The older parts of Liman 3 were built in the 1970s and constructed as dormitory neighborhood, typical for the urbanization of that time. Only a few buildings were designed to have shops at the ground level, while the number of individual non-residential buildings was negligible. For many years, the main non-residential facilities were a primary school and two preschool institutions. Over the time, the lack of service sector facilities has been solved by the transformation of ground-floor rooms, but also by raising a large number of kiosks at the most frequent locations, while some apartments on higher floors have been rearranged into offices $^{5}$. Only at the end of the $20^{\text {th }}$ and the beginning of the $21^{\text {st }}$ century, favorable conditions were created for more intensive construction of non-residential facilities, which resulted in a changed relationship between the primary uses, and consequently in the development of secondary ones. Today, residential, primary non-residential and secondary non-residential uses are in following ratio $72 \%: 17 \%: 11 \%$ (Graph 3).
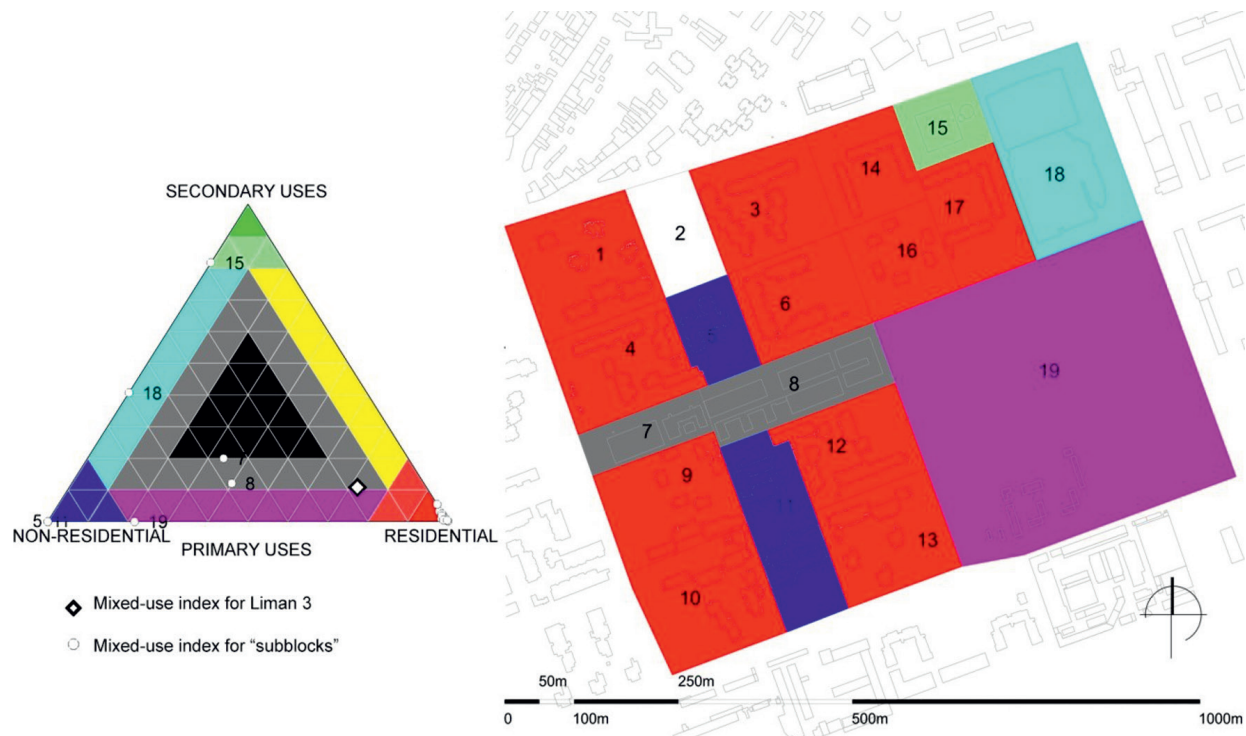

Graph 3. Diagram of the mixed-use and representation by blocks

Source: M. Carević Tomić

\footnotetext{
${ }^{5}$ Large amount of office space were acquired by reconstruction of a parts of apartments, which was previously prevented by a series of regulations (Milosavljević 1994).
} 
The business-commercial zone of Liman 3, along Bulevar oslobodjenja Street, has been developed as a part of the new city centre. However, although the opening of the headquarter of oil industry company of Serbia "NIS" (1998) has induced a large number of jobs, given the company's profile, size, and the global market orientation, it has no greater local influence on flows and vitality of near surrounding. It is similar to the Mercator supermarket (opened in 2007), which functions as a living, but quite an introvert system.

Regarding the local center along Narodnog fronta Street, it has great importance for the local neighborhood, even though for many years it has not been conformed to designated use, except for one business facility. The local center has been finally formed at the beginning of the $21^{\text {st }}$ century when a mixed-use complex "Park City" was built - where the IT sector is dominant when it comes to non-residential facilities. The introduction of new programs has initiated regeneration of ground floors of surrounding older buildings, but the issue of insufficient activation of open spaces in-between buildings of the local center is still present and has multiple explanations. Besides the inadequate integration of the pedestrian network segments and unsatisfactory visibility from the main street, the ground floors of the Park City complex, which shape this area, are intended for large-format premises. There is obviously an insufficient demand for this kind of business facilities, so some of them are rearranged into offices as primary non-residential uses which, however, do not activate facade front, while the rest of the premises are still empty. However, considering the staying in the space, the biggest problem is the lack of the attractive open spaces - due to the lack of the street furniture and unregulated parking.

Limanski park represents a large park area significantly contributing to the quality of life of the entire neighborhood. Over the years, increased diversity of facilities has been developed for diverse categories of users in the park, which support the greater attendance of people. The study of green and recreational areas of Novi Sad (2009) showed that the visitors of Limanki park are the most regular users in relation to respondents in other parks. The study also revealed that there is a greater share of those who declared that they establish new contacts and acquaintances in the park, which leads to the conclusion that the park is a significant source of social capital.

Typologically observed, the fragment of Liman 3 belongs to the group of moderately mixed-use neighborhoods with the prevailing share of housing. Separately in segments or sub-blocks, monofunctionality with the domination of one of the three elementary uses is still observed. The exception is only the local center along Narodnog fornta street, where the ratio of the elementary uses is more balanced. In other words, the functional structure of the neighborhood is of a coarse grain - the monofunctional buildings prevail, while uses are combined exclusively horizontally for the largest part of the fragment. Only present-day 
architectural interventions have introduced more complex ways of combining programs, meaning that, for example, the same building contains both horizontal and vertical mixing of uses.

\section{Conclusions}

The observed fragment of Liman 3 has been developed for over 40 years, from a completely residential to moderately mixed-use neighborhood. The gradual introduction of primary non-residential uses, along with the development of entrepreneurship and other socio-economic circumstances, has also created favorable conditions for the initiation of programs and activities in the field of secondary uses. Their disposition in space, i.e. concentration along the busiest streets, but at the same time in areas where there is a mixture of primary uses of higher capacity ${ }^{6}$, confirms the dependence of the development of secondary uses based on these two aspects. High FAR followed by greater residential density, together with constantly increasing number of employees, ensure adequate concentration of users for secondary uses. Explicit obstacle for further boasting of the service sector in the area of mixed primary uses, is the lack of an adequate space - premises of smaller surface area adjusted for the activities of local significance.

Since the completion of the music and ballet school will fulfill planned capacities, it is certain that new primary programs will not be constructed in the near future. Therefore, we may conclude that the current ratio between elementary uses will keep the status quo. Possible improvements may be found in the form of a permanent solution for temporary shops/kiosks and street vendors, which would improve the overall experience in the space. Small GSI that is common for post-war neighborhoods allows the interpolation of new structures without disturbing the existing conditions of living comfort. Also, many post-war areas, are characterized by significant transformability of the ground floors because of the auxiliary rooms positioned there - an extensive study conducted on the neighborhoods in Novi Sad has shown that the auxiliary rooms in the ground floors are more easily and more frequently converted to non-residential uses (especially secondary) than apartments.

In summary, we may conclude that the complex combination of causes leads to an exact land-use pattern, while the wider socio-economic and cultural context, and the accessibility are the two most important factors determining

${ }^{6}$ When one primary use is successfully combined with another, owing to which people appear on the street at different times, then their common performance can be economically stimulating: thus, a fertile environment is formed to flourish the secondary diversity, that is, economic and other activities that appear as a consequence of already existing primary content/programs (Džejkobs 1961/2011). 
the multifunctionality in a certain part of the city. In addition, the position of the area in relation to the center of the city, as well as the building and residential density, are to be highlighted, as creating favorable conditions for the spontaneous development of secondary uses.

\section{Acknowledgement}

The paper was done within the project „Optimization of architectural and urban planning and design in function of sustainable development in Serbia" (TR36042), funded by the Ministry of Education and Science, Republic of Serbia.

\section{Bibliography}

Berghauser Pont M., Haupt P., 2009, Space, Density and Urban Form, Delft.

Carević M., 2017, A tool for optimization of mixed-use planning, [in:] Kurtović Folić N.,

Krklješ M. (eds.), Optimizacija arhitektonskog i urbanističkog planiranja i projektovanja u funkciji održivog razvoja Srbije, Fakultet tehničkih nauka, Novi Sad.

Džejkobs D., 1961/2011, Smrt i život velikih američkih gradova, Mediterran Publishing, Novi Sad.

Hillier B., 2009, The genetic code for cities - is it simpler than we think?, [ in:] Portugali J. et al. (eds.), Complexity theories of cities have come of age, TU Delft, Delft: 129-152.

Jovanović S., 2011, Arhitektura Novog Sada druge polovine XX veka, Društvo arhitekata Novog Sada - DaNS, Novi Sad.

KLER, 2011, IT City - Novi Sad evropski IT centar, Kancelarija za lokalni ekonomski razvoj, Novi Sad.

Milosavljević M., 1994, Urbanizam u Novom Sadu između dva broja DaNS-a, DaNS br. 9-10, 26-27, Novi Sad.

Nedučin D., 2014, Postsocijalistički grad - promena društvene i prostorne strukture Novog Sada u periodu tranzicije, PhD dissertation, Novi Sad.

Poljoprivredni fakultet Univerziteta u Novom Sadu, 2009, Studija zelenih i rekreativnih površina, Novi Sad.

Pušić L., 2009, Grad bez lica, Mediterran Publishing, Novi Sad.

Srbulović D., 2000, Kratka istorija Novog Sada, Prometej, Novi Sad.

van den Hoek J., 2009, The Mixed Use Index (MXI) as Planning Tool for (New) Towns in the $21^{\text {st }}$ Century, [in:] Provoost M. (ed.), New Towns for the $21^{\text {st }}$ Century: the Planned vs, the Unplanned City, Almere, The Netherlands.

\section{ZRÓŻNICOWANIE FUNKCJONALNE POWOJENNYCH OSIEDLI MIESZKANIOWYCH - PRZYKLAD NOWEGO SADU (SERBIA)}

Zarys treści: $\mathrm{W}$ artykule przedstawiono przykład osiedla mieszkaniowego o nazwie Limans w Nowym Sadzie, w Serbii. Studium przypadku stanowi jego część o nazwie Liman 3. Jest to dobry przykład świadczący o stopniowej funkcjonalnej dywersyfikacji osiedla od czasów powojennych do dzisiaj. Podejście badawcze Autorek opiera się na połączeniu narzędzi: Space Syntax, Spacematrix i Mixed-use index. Wykorzystano także analizę 
kontekstualną ze szczególnym uwzględnieniem zagadnień społecznych i gospodarczych. Celem artykułu jest pokazanie, w jaki sposób lokalna specyfika w połączeniu z globalnymi wpływami spowodowały przejście od całkowicie mieszkaniowego do umiarkowanie mieszanego osiedla w ciągu ponad 40 lat rozwoju.

Słowa kluczowe: Nowy Sad, osiedla mieszkaniowe, wzory użytkowania gruntów, zastosowania mieszane, Mixed-use index.

Marina Carević Tomić, PhD

Department of Architecture and Urban Planning

Faculty of Technical Sciences

University of Novi Sad (Serbia)

e-mail:marinac@uns.ac.rs

Ranka Medenica, $\mathrm{PhD}$

Department of Architecture and Urban Planning

Faculty of Technical Sciences

University of Novi Sad (Serbia)

e-mail: ranka.medenica@uns.ac.rs 